The Canadian Journal of Higher Education, Vol. XXV-3, 1995

La revue canadienne d'enseignement supérieur, Vol. XXV-3, 1995

\title{
Supervision of Graduate Students
}

\section{EDWARD HOLDAWAY, ${ }^{*}$ CLAUDE DEBLOIS,${ }^{\dagger}$ \& IAN WINCHESTER ${ }^{\triangle}$}

\begin{abstract}
Graduate education is an essential component of universities; it also contributes substantially to national economies. However, problems in graduate education, especially with respect to completion and quality, have emerged in many countries, including Canada. To address these problems and related issues and practices, a comprehensive three-year research project has been conducted involving questionnaires and interviews in Canada, Australia, Great Britain, and other countries. This paper presents information from questionnaires completed in 1993 by 736 supervisors of graduate students in 37 universities across Canada. Many substantial differences were obtained between the means for items when respondents were classified into eight discipline areas. The responses related to master's and doctoral programs were generally similar.
\end{abstract}

\section{Résumé}

Les études de $2 e$ et $3 e$ cycles constituent une composante essentielle des programmes offerts par les universités. En outre, ces programmes d'études supérieures contribuent de façon subtantielle aux économies nationales. Tout récemment, les problèmes liés à ces programmes d'études ont fait surface dans

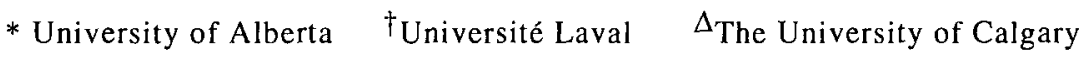

The authors gratefully acknowledge (a) the financial assistance provided by the Social Sciences and Humanities Research Council of Canada in the form of a research grant, (b) the cooperation of the respondents, and (c) the help given by Susan Bens, Christopher Elford, Tracey Kremer, James MacLeod, Christiane Prokop, and Geoffrey Riordan. 
plusieurs pays dont le Canada. On s'interroge surtout sur la qualité de ces programmes et la durée requise pour les compléter. Pour répondre à ces interrogations d'ordre général et pratique, nous avons mené une importante recherche qui a duré trois ans et qui s'est étendue à plusieurs pays dont le Canada, l'Australie, la Grande Bretagne, et plusieurs autres. La cueillette des données s'est faite à l'aide de questionnaires et d'entrevues.

Cet article fait état des résultats obtenus à l'aide de questionnaires administrés en 1993 auprès de 736 directeurs d'études supérieures dans 37 universités canadiennes. Ces résultats ont révélé des différences significatives quant aux moyennes obtenues sur chacun des items lorsque les répondants étaient regroupés en 8 secteurs disciplinaires. En ce qui a trait aux programmes de maîtrise et de doctorat, les réponses aux questions étaient assez semblables.

Graduate education is viewed in many countries as essential for the viability of universities and national economies. However, some major problems have been identified in graduate education, especially with respect to (a) completion times and percentages, and (b) the quality of programs and students. Procedures and practices related to these problems have received attention, especially with respect to supervision, funding of students, program requirements, and facilities. Canadian concerns about problems with graduate education, especially long completion times, have been expressed by The Royal Society of Canada (1991), the Canadian Association for Graduate Studies (1992), the Association of Universities and Colleges of Canada (1992), and Stuart Smith (1991).

This article presents the results of analyses of some information obtained during the second part of a research program on the organization and administration of graduate programs. The purpose of the research was to obtain the opinions of experienced supervisors of graduate students about matters identified as important either in the literature or in interviews conducted earlier in the research program. Responses were also classified by (a) eight discipline areas and (b) whether they related to master's or doctoral programs.

\section{Overview of Literature}

A considerable body of international literature now exists on supervision of graduate students. Some of this is based on research, such as surveys completed by supervisors and students, while other writings involve learned opinion related to supervisory experience. Research and experience have identified differences in graduate education relevant to the discipline being studied and researched, whether the students are full-time or part-time, and the extent to 
which graduate education is directed at professional education or the preparation of academics/researchers.

At the outset, the two aspects of supervision described by the Council of Graduate Schools (1990) should be mentioned. The first, dealing with "creativity," was defined as "the ability to select problems, to stimulate and enthuse students, and to provide a steady stream of ideas," while the second involves "the mechanics of ensuring that the student makes steady progress" (p. 1). The selected quotations in this article demonstrate both the importance and the diversity of the graduate supervisor's role.

\section{Creativity, Mentoring, and Support}

Blume (1987) addressed the apprenticeship aspect of graduate studies which has found favor among several writers in this way: "The supervisory relationship must be significantly based in the moral and collegial responsibilities of the old system of apprenticeship in scholarship" (p. 15). This relationship has been tied by Moses (1985) to the matter of mutual expectations:

In my survey of supervisors and postgraduate research students in one [Australian] science department concerning their expectations of each other, supervisors expected students to be diligent, dedicated, and hard working; to be energetic, keen, tenacious, conscientious, and have a sense of urgency. They also expected students to be enthusiastic and motivated towards research work, be pleasant at work and contribute to a good work environment. Students expected their supervisors foremost to have knowledge and ability to supervise that particular area of research, secondly to be reasonable, serious, supporting the student's work in good times and bad, and to be understanding and approachable. (p. 37)

Based on 781 interviews with university administrators, faculty, students, alumni, and employers of graduates from 47 master's programs in the U.S., Conrad, Haworth, and Millar (1993) concluded that active faculty involvement, unity of purpose, strong program leadership, and a supportive learning environment were some of the attributes of high-quality master's programs. The supportive aspect was also addressed by Moses (1992) who considered that supervisors should act as mentors and that a mentoring relationship requires mutual respect based on high academic standards, similar interests, assistance, support, and regular contact (p. 15). However, Gumport (1993) observed that because many graduate students are involved with sponsored research projects, their supervisors are more like project managers than mentors, and consequently the students are treated more like employees than apprentices (p. 241). 
The importance of interpersonal relations in graduate supervision was stated more directly by Ballard and Clanchy (1993):

Successful supervision of graduate students always involves a blend of academic expertise and the skillful management of personal and professional relations. Supervisors are expected to be knowledgeable and skilled in their disciplinary specialties, and they are also expected to take the lead in establishing a quality of relations which will give their students access to the knowledge and skills they possess. This second expectation takes on both a new dimension and a greater intensity in the supervision of overseas or international students. (p. 61)

Similarly, Salmon (1992) brought attention to the importance of the human aspect of supervision when she stated that "the quality that supervision needs above all to offer is that of personal support" (p. 20).

The balance between use of a directive supervisory style and graduate student independence was addressed by Hill, Acker, and Black (1994). In their study of supervisory practices in three U.K. universities they noted substantial variation between the emphasis placed by individual supervisors on direction versus independence. Also, Burgess, Pole, and Hockey (1994) concluded that "most supervisors adopt a degree of flexibility in their approach to supervision in an attempt to meet the needs of individual students" (p. 26). Based on their research in nine U.K. universities, they considered that the approach taken to supervision depends on the supervisor's assessment of the student's intellectual capacity, the supervisor's own doctoral experience, the student's expertise, and the stage of the thesis research.

After reflecting upon their experiences and research findings in U.K. universities, Phillips and Pugh (1987) advised supervisors to take these actions: (a) be aware of students' expectations and try to fulfill them; (b) be aware that you inevitably act as a role model; (c) be aware that supervision is an educational process that requires careful planning; (d) keep students' morale high; (e) set up a helpful climate in which agreements are outlined; and (f) look for ways to support graduate students in their careers (pp. 119-120).

\section{Procedures to Ensure Progress}

Several writers have encouraged the holding of regular meetings of supervisors and their graduate students. For example, Bowen and Rudenstine (1992) highlighted this aspect together with the need to establish a schedule:

It would be difficult to overemphasize the need for regular, scheduled meetings between students and dissertation advisers (or committees) throughout the process, with clear expectations about a work 
schedule and a timetable for completion of drafts. Faculty must take the initiative in creating and managing this process or structure. Otherwise, many students will drift, or simply be lost. (p. 284)

The need to have a completion schedule was also emphasized by Smith (1991) in his report to the Association of Universities and Colleges of Canada:

Supervisors should be required to report to their departments the exact status of each graduate student, the schedule for completion (with precise milestones) and the reasons for any changes in the scheduling. Each report should be reviewed by the graduate student and be approved by him/her. Departments should hold supervisors responsible for bringing about timely outcomes as predicted. (p. 107)

Further, based on her research at The University of Melbourne, Powles (1989) identified the need for regular reporting:

In general, the more input supervisors said they had, the higher their students' satisfaction ratings. Much emphasis was placed by students and supervisors on the importance and usefulness of regular progress reporting either in the form of written submissions or oral reports of a formal (seminar-type) kind. Arts candidates have never done the latter in a majority of cases. (p. 51)

Powles (1993) also pointed out that increasing graduate enrolments and the need to improve the quality of graduate supervision require the use of "advisers with some expertise on supervisory matters" and that "it is widely recognized that being in command of one's field and being an active researcher with a $\mathrm{PhD}$ oneself are essential pre-requisites, but these do not guarantee good supervisory practice" (p. 79). The need to insist on higher standards of graduate supervisors, especially to reduce completion times, was recommended by The Royal Society of Canada (1991). Bowen and Rudenstine (1992) considered that thesis advisers "should be evaluated with respect to their performance as advisers" and that "it is difficult to think of responsibilities that are more important than dissertation advising, and the case for careful, and sensitive, evaluation seems compelling" (p. 284).

The amount of assistance given to graduate students by their supervisors varies depending upon the stage that the students have reached. Moses (1992) identified the early and late stages as the most crucial and also stated that "students need guidance in particular on when to stop data collection and analysis, and when to start drafting the thesis, and assistance with structuring of the thesis" (p. 14). Salmon (1992) also advocated that graduate students need substantial help in achieving an appropriate orientation to the final oral examination (p. 28).

Some Canadian universities are focusing attention on the nature and quality of graduate supervision on their campuses. For example, Donald, Saroyan, and 
Denison (1994) conducted a study at McGill University to identify salient issues and to examine (a) policies relevant to assignment of supervisors, collaboration, and financial assistance, and (b) the importance attributed to academic advising.

\section{Differences Among Disciplines}

A few writers have identified differences in practices among disciplines with respect to graduate studies. For example, Moses (1992) had this assessment:

The role of the supervisor(s) in the selection of the topic varies between broad fields of study; in some areas, notably the humanities, some supervisors would argue that topics should not be assigned to students, but that students should choose supervisor and topic. In other areas, notably those with external funding for projects and team research, suggestions to students about both supervisor and topic is more likely to occur. But in no field was it seen as good practice to assign a topic to students, nor to allow students to choose a topic without having discussed its feasibility and viability with their supervisor. (p. 11)

Donald et al. (1994) confirmed that some important differences do exist between discipline areas with respect to supervisory practices. For example, they concluded that at McGill University "in the physical and biological sciences . . . knowledge of the research field is the paramount requirement of a supervisor, while in others, responsiveness to students (availability, motivation, sensitivity) takes precedence" (p. 18).

After surveying aspects of graduate education in Canadian universities, Holdaway, Deblois, and Winchester (1994) reported several differences between disciplines. The most notable were, first, transfer to a doctoral program without completing the master's program is substantially more common in Medicine, Biology, and Physical Sciences than in other discipline areas. Second, in Education, Social Sciences, and Humanities, graduate students choose their thesis topic themselves more frequently than do other students. Third, Humanities graduates were far more likely to have been the sole author of publications resulting from their research than were graduates in the other discipline areas. Finally, lack of financial support was perceived to be a reason for non-completion of graduate students in Humanities far more commonly than for other students.

\section{Synthesis}

In the U.K. Science and Engineering Research Council publication entitled Checklist on good supervisory practice, Christopherson et al. (1992) contributed 
a synthesis of many of the aspects raised in the literature cited above. This publication emphasized distribution of a departmental document on good supervisory practice, a good student-supervisor match, regular reporting and discussions, public presentations, early topic selection, research program with a critical path, checks on student's record keeping, completion of research in three years, and holding of a mock final oral examination. Further synthesis is provided by the conceptual framework in Figure 1 which demonstrates the linkage between some aspects of inputs, process (supervision and activities of student), outputs, assessment of quality of graduate program, and feedback.

\section{Method}

In one of the early phases of this study, graduate deans (or equivalent) in 38 Canadian universities were asked to supply information about aspects of the organization and administration of graduate programs. Most of the 37 universities from which information was obtained were used in later phases of the study together with three other universities. In 1992, comprehensive questionnaires were mailed to 892 coordinators of graduate programs in 37 Canadian universities. These programs constituted all of the Canadian graduate programs which were estimated to have at least 20 graduate students. Of the 892 approached, 582 returned completed usable questionnaires for a $65 \%$ return rate. The graduate coordinators were also asked to identify two experienced graduate supervisors who were likely to be on campus in 1993-94. A total of 1,100 experienced supervisors were so identified. Comprehensive questionnaires were mailed in early 1993 to these 1,100 supervisors of graduate programs in the 37 Canadian universities; 736 usable responses were obtained. Respondents indicated that 35 supervisors either had been incorrectly identified or were no longer on campus. Based on 1,065 eligible supervisors (1,100 minus 35$)$ the response rate was $69 \%$.

Information was sought from these "experienced supervisors" about selection of supervisors, supervisory practices, supervisory load, assistance with students in various phases of their research, development of students' skills, and assistance with manuscripts and conference proposals. The questions which had numerical/descriptive response categories (e.g., 5 = "Always") were based upon opinions, practices, and issues which either were raised in the literature cited above or were identified in interviews conducted in earlier phases of this study. Free responses were also invited on any relevant aspect. Pilot-testing of the draft questionnaire resulted in several modifications. Descriptive statistics were used in the analyses, and responses were categorized by major discipline area and by master's or doctoral program. 
Figure 1

Relationships among selected variables in graduate education relevant to supervison

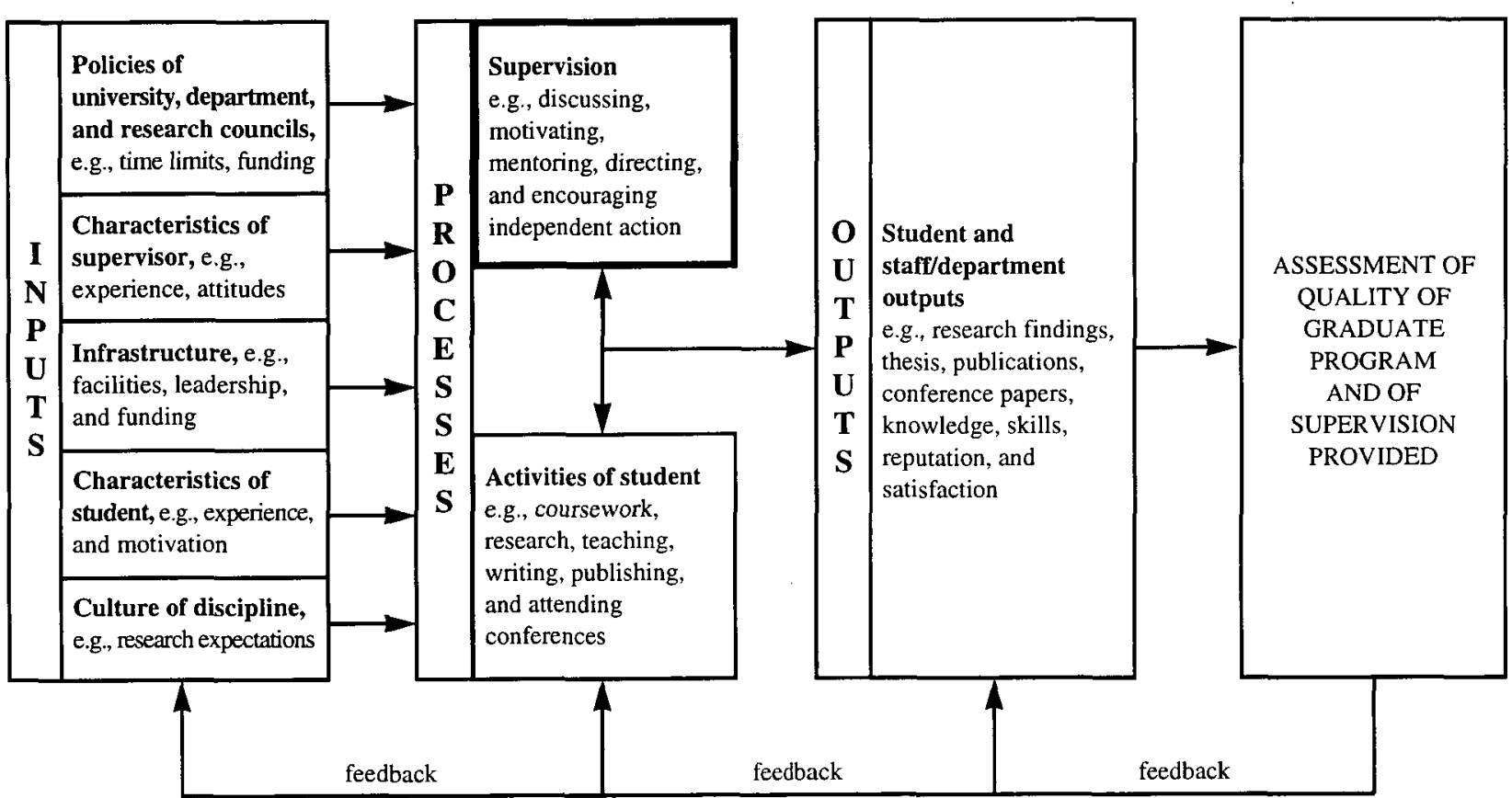


Inferential statistics were not used because the experienced supervisors who responded were not a representative sample of all Canadian graduate supervisors. Differences between means could therefore not be tested for statistical significance. For differences between percentages on the 1-5 scales to be considered "Substantial" an arbitrary difference of 0.30 above or below the mean was set. Similarly, gross differences in percentages of agreement with propositions (e.g., 65\% vs. 35\%) were assumed to indicate real differences in attitude between disciplines. Some generalizations about each of the eight discipline areas were then developed based upon both similarities and differences in the supervisors' responses. Of course, the data in Tables 2 to 5 can be analyzed in different ways using different criteria to indicate the extent to which substantial variation occurred between disciplines. The major original contribution of this paper is the provision of data about the opinions of expert supervisors in various discipline areas.

\section{Respondents}

The percentage frequency distribution of the respondents' discipline areas is shown in Table 1. In order of decreasing frequency of respondents the major disciplinary areas were Social Sciences $19.2 \%$, Biology $17.8 \%$, Humanities $14.9 \%$, Education $12.6 \%$, Health $11.4 \%$, Physical Sciences $11.4 \%$, Engineering $9.4 \%$, Business $2.9 \%$, and Interdisciplinary $0.6 \%$. The percentage frequency distribution of geographic regions of respondents was as follows: (a) Newfoundland, Nova Scotia, and New Brunswick - 12.1\%; (b) Québec 25.2\%; (c) Ontario - 33.2\%; and (d) Manitoba, Saskatchewan, Alberta, and British Columbia $-29.4 \%$. Geographic location was not used in the analyses.

\section{Results}

Selected representative results obtained from the questionnaires are presented below using these approaches: (a) presentation of overall means or overall percentages; (b) comparison of means or percentages for the responses classified by the major discipline groups; and (c) comparison of means or percentages of responses relevant to master's and doctoral programs. Selected illustrative quotations from the respondents' comments provided on the questionnaires are interspersed in italics. The quotations were selected because they provided insights into supervision from faculty members assessed as "experienced supervisors." Some quotations represent conflicting viewpoints whereas others are complementary. They do not necessarily represent widely shared 
Table 1

Percentage Frequency Distribution of Academic Disciplines of Respondents ( $n=727$ )

\begin{tabular}{lll}
\hline Academic discipline & \%f & Total \%f
\end{tabular}

\section{BIOLOGY}

Agriculture, Forestry, and/or Biological Sciences $\quad 17.2$

Veterinary Medicine $\quad 0.6$

17.8

ENGINEERING

$\begin{array}{ll}\text { Architecture } & 0.7\end{array}$

$\begin{array}{ll}\text { Engineering } & 8.7\end{array}$

9.4

\section{BUSINESS}

Business/Commerce $\quad 1.8$

Public Administration $\quad 1.1$

\section{PHYSICAL SCIENCES}

Physical Sciences

Computing Science

2.1

Mathematics and/or Statistics

\section{HEALTH}

Dentistry

Medicine

Nursing

Pharmacy

Rehabilitation Medicine

\section{EDUCATION}

Education

Physical Education and/or Recreation

\section{SOCIAL SCIENCES}

Social Sciences

Home Economics

Law

Library Science

Psychology

Social Work

\section{HUMANITIES}

Humanities

Fine Arts 
opinions, although some were typical of the views of many respondents. The means for each discipline area and the total means for all responses are shown in Tables 2, 3, 4, and 5. Because its size was very small the Interdisciplinary group was not included.

The questions in the supervisors' questionnaire were sorted into groups of questions in the tables on these bases: (a) Table 2 contains general questions about supervisory relationships (input, process, and output variables in Figure 1); and (b) Tables 3, 4, and 5 contain questions relating to the importance of aspects of supervision-at the university, unit, and supervisor level respectively-in assisting thesis students to complete their theses and pass oral examinations in an appropriate period of time (input and process variables in Figure 1).

The detailed results in the tables are usually not repeated in the text of this article; the emphasis is on producing generalizations about various aspects of supervision and on identifying similarities and differences between disciplines.

\section{Research Relationships}

Supervisors were asked to indicate how frequently students' thesis research projects were an integral part of or closely related to their supervisor's research activities. The overall means for master's and doctoral programs were 3.65 and 3.86, which occur between "Often" (3) and "Usually" (4). Biology, Engineering, Physical Sciences, and Health had substantially higher master's-level means (4.034.25) for this relationship than did the Humanities, Education, and Social Sciences (2.96-3.23). For doctoral students, the same discipline groupings were obtained with the four highest means being 4.19-4.33 and the lowest three 3.25-3.42.

The following quotations indicate the types of issues that emerge in the relationship between students' and supervisors' research in specific disciplines:

It seems clear that different constraints operate in the humanities vs. sciences owing to financial requirements of sciences. Students in science must work on projects of their supervisor's origin with relatively limited room for digression, relative to what is possible in other disciplines. (Agriculture/Biology)

In the humanities-where individual research is the norm-advisors must be scrupulous about the relations between theirs and their students' research. If a student is working in exactly the same area, the responsibility is the advisor's not to overlap. (Humanities)

I think that students at the master's and doctoral levels would profit from being invited to be more closely associated with the scientific activities of their department and participating in those activities. It would be good for them not to feel too isolated in their research. 
It would be good to create ways of integrating these students so that they have the feeling of being at a level that is truly different than that of undergraduate students. (Law)

Key to success-match student interests with those of a potential supervisor before accepting student. (Physical Sciences)

\section{Maximum Supervisory Load}

Just over half (54\%) of the respondents considered that the maximum number of graduate students on thesis programs that one faculty member can supervise should be restricted. The highest level of agreement occurred for Business respondents (75\%) and the lowest in Engineering (32\%) and Biology (39\%). Those who favored a restriction identified the maximum number. The overall mean maximum number was 5.18, with the highest maximum being obtained for Education (5.71), Physical Sciences (5.60), and Humanities (5.57), and the lowest for Health ( 4.36).

Of course, the maximum number of graduate students who can be supervised effectively by any one faculty member depends upon other aspects of workload such as undergraduate and graduate teaching, administration, service, research, and involvement with postdoctoral fellows. The supervisory workload also depends upon the stages that master's/doctoral students are at with respect to their thesis research as well as aspects such as complexity of the research and the students' competence and diligence.

Graduate supervision, like undergraduate teaching, should be assigned teaching credit. Therefore the number of graduate students assigned to individual faculty must be determined by program and overall teaching needs. (Area not identified)

The work load of "active" professors seems to get heavier and heavier. It would be extremely important to treat student supervision as seriously as group teaching, thus a sort of quantification is necessary. (Humanities)

Depends on the ability of the supervisor; supervisors are not clones! Some have a problem with one student, whereas others are able to handle 5-6 with no problems. (Medicine)

\section{Assistance Provided to Students}

Table 2 presents the distribution of supervisors' responses about the extent to which supervisors, or faculty members in the case of Question 1, should assist graduate students in certain functions. Questions 1 to 4 are related to 
thesis tasks. The highest level of support was obtained for faculty members assisting in development of thesis research proposals (master's level mean 4.23; doctoral 4.00). Assistance with refining and improving theses before the final oral examination was only slightly less supported $(4.06 ; 3.82)$, while assistance with data analysis (3.33 and 2.92) and collection of data (2.70 and 2.41) were both substantially less supported. In all four functions, greater support for master's students was indicated than for doctoral students.

Questions 5 to 8 in Table 2 are related to assistance with non-thesis functions for doctoral students. The supervisors' responses showed "Some" to "Substantial" support for assistance in preparation of journal manuscripts (mean=3.83), preparation of conference paper proposals (3.69), development of teaching skills (3.58), and development of skills in preparing research grant applications (3.48). These results show that the Canadian supervisors in this study placed considerable importance upon development of skills and preparation of academic papers and proposals, in addition to providing help with aspects of thesis research and thesis production.

Supervisors should also encourage students to attend conferences, make presentations, and otherwise expose students to discuss their work with visitors working in the area. (Physical Sciences)

Any presentation, written or oral, is a reflection of the lab in which the student is working. Graduate training should be teamwork between the supervisor and graduate student. (Medicine)

\section{Importance of Supervisory Aspects}

Data about the supervisors' responses concerning the importance of aspects of supervision-at the university, unit, and supervisor levels-for completing theses and passing final examinations in an appropriate period of time are shown in Tables 3, 4, and 5.

For master's programs, the highest importance was placed on providing prompt feedback on draft chapters (mean=4.47), ensuring that the thesis project does not grow excessively (4.39), helping to revise research design if unforeseen problems require this (4.37), holding regular progress report meetings (4.37), ensuring continual progress (4.21), providing a graduate student handbook (4.15), providing balance between direction and independence (4.11), and assigning supervisors who are expert in the student's specific research fields (4.06). All these means were above "Considerable" (4) on the response scale. For doctoral programs the results were similar except that the doctoral means were somewhat higher for these functions: (a) for providing balance between direction and independence (4.35 vs. 4.11 ); (b) for assigning supervisors who 


\begin{tabular}{|c|c|c|c|c|c|c|c|c|c|c|c|}
\hline \multirow[b]{2}{*}{ QUESTION } & \multirow[b]{2}{*}{ Level } & \multicolumn{8}{|c|}{ Means of Responses } & \multirow[b]{2}{*}{$\mathrm{n}$} & \multirow{2}{*}{$\frac{\text { Mean }}{\text { Total }}$} \\
\hline & & Biol & Eng & Bus & PhySci & Health & $\mathrm{Ed}$ & SocSci & Hum & & \\
\hline \multirow{2}{*}{$\begin{array}{l}\text { 1. To what extent should faculty members } \\
\text { of your academic unit, through courses, } \\
\text { seminars, discussions and other activities, } \\
\text { assist their students in development of } \\
\text { their thesis research proposals? }\end{array}$} & Master's & 4.46 & 4.25 & 3.85 & 4.38 & 4.39 & 4.15 & 4.13 & 3.99 & 715 & 4.23 \\
\hline & Doctoral & 4.08 & 3.84 & 3.69 & 4.19 & 4.00 & 4.06 & 3.91 & 3.97 & 679 & 4.00 \\
\hline \multirow{2}{*}{$\begin{array}{l}\text { 2. To what extent do you consider that } \\
\text { supervisors should assist their graduate } \\
\text { students in collection of data for } \\
\text { their theses? }\end{array}$} & Master's & 3.01 & 2.93 & 2.30 & 3.28 & 2.77 & 2.21 & 2.50 & 2.42 & 691 & 2.70 \\
\hline & Doctoral & 2.66 & 2.60 & 2.25 & 2.95 & 2.23 & 2.01 & 2.23 & 2.28 & 664 & 2.41 \\
\hline \multirow{2}{*}{$\begin{array}{l}\text { 3. To what extent do you consider that } \\
\text { supervisors should assist their graduate } \\
\text { students in analyses of data for } \\
\text { their theses? }\end{array}$} & Master's & 3.53 & 3.37 & 2.95 & 3.51 & 3.73 & 3.19 & 3.07 & 3.15 & 697 & 3.33 \\
\hline & Doctoral & 3.07 & 2.84 & 2.75 & 3.01 & 3.09 & 2.84 & 2.67 & 2.94 & 670 & 2.92 \\
\hline \multirow{2}{*}{$\begin{array}{l}\text { 4. To what extent do you consider that } \\
\text { supervisors should be involved in assisting } \\
\text { their graduate students in the refinement } \\
\text { and improvement of their theses prior to } \\
\text { the final oral examination? }\end{array}$} & Master's & 4.10 & 3.87 & 4.20 & 4.16 & 4.16 & 4.09 & 3.96 & 4.05 & 705 & 4.06 \\
\hline & Doctoral & 3.73 & 3.51 & 4.13 & 3.93 & 3.74 & 3.94 & 3.78 & 3.96 & 687 & 3.82 \\
\hline
\end{tabular}


Table 2 (continued)

\begin{tabular}{|c|c|c|c|c|c|c|c|c|c|c|c|}
\hline \multirow[b]{2}{*}{ QUESTION } & \multirow[b]{2}{*}{ Level } & \multicolumn{8}{|c|}{ Means of Responses } & \multirow[b]{2}{*}{$\mathrm{n}$} & \multirow{2}{*}{\begin{tabular}{|l} 
Mean \\
Total
\end{tabular}} \\
\hline & & Biol & Eng & Bus & PhySci & Health & Ed & SocSci & Hum & & \\
\hline $\begin{array}{l}\text { 5. To what extent do you consider that } \\
\text { universities should assist doctoral students } \\
\text { in development of their teaching skills? }\end{array}$ & Doctoral & 3.64 & 3.39 & 3.67 & 3.48 & 3.59 & 3.50 & 3.50 & 3.82 & 704 & 3.58 \\
\hline $\begin{array}{l}\text { 6. To what extent do you consider that } \\
\text { supervisors should assist doctoral students } \\
\text { in development of their skills in preparing } \\
\text { research grant applications? }\end{array}$ & Doctoral & 3.55 & 2.82 & 3.38 & 3.12 & 3.86 & 3.66 & 3.45 & 3.66 & 702 & 3.48 \\
\hline $\begin{array}{l}\text { 7. To what extent do you consider that } \\
\text { supervisors should assist doctoral students } \\
\text { in preparation of proposals to present } \\
\text { papers at conferences? }\end{array}$ & Doctoral & 3.94 & 3.65 & 3.57 & 3.91 & 4.07 & 3.64 & 3.33 & 3.47 & 707 & 3.69 \\
\hline $\begin{array}{l}\text { 8. To what extent do you consider that } \\
\text { supervisors should assist doctoral students } \\
\text { in preparation of manuscripts for submissior } \\
\text { to refereed journals? }\end{array}$ & Doctoral & 4.23 & 3.91 & 3.71 & 4.15 & 4.23 & 3.69 & 3.39 & 3.44 & 711 & 3.83 \\
\hline $\begin{array}{l}\text { 9. To what extent does agreement exist } \\
\text { between the expectations of supervisors }\end{array}$ & Master's & 3.90 & 3.67 & 3.50 & 4.01 & 3.84 & 3.78 & 3.69 & 3.67 & 618 & 3.79 \\
\hline $\begin{array}{l}\text { and graduate students concerning the } \\
\text { quality of thesis supervision provided } \\
\text { in your academic unit? }\end{array}$ & Doctoral & 3.94 & 3.64 & 3.46 & 3.99 & 3.78 & 3.70 & 3.70 & 3.63 & 549 & 3.77 \\
\hline
\end{tabular}

Note: These questions used this response scale: $1=$ Not at all; $2=\mathrm{A}$ little; $3=$ Some; $4=$ Substantial; $5=\mathrm{A}$ great deal; ( $9=$ Not applicable or No opinion). 
are expert in the students' specific research fields (4.30 vs. 4.06 ); and (c) providing settings in which students can present progress reports (4.16 vs. 3.90 ).

Our program requires submission of a progress report by the supervisor for each student every semester, with a copy going to the student. (Physical Sciences)

Progress reports have been implemented in our unit and we hope to improve the flow and timely completion especially at the master's level. (Fine Arts)

The matching of supervisors/students should not be done unilaterally by the unit. This should be achieved by mutual agreement between students and available potential supervisors. (Physical Sciences)

\section{Characteristics of Disciplinary Groups}

Categorization of the supervisors' responses allowed syntheses of the characteristics of discipline groups to be developed. Because these supervisors were experienced and were located in universities across Canada these syntheses should be viewed as reasonably representative of the disciplines. However, they must also be seen as generalizations which do not necessarily apply to all supervisors and which warrant further research. In order to simplify the presentation only the responses for doctoral programs have been used in this section.

Similarities. Initially, those aspects of supervision for which the means were similar must be identified. The nine aspects for which the range of discipline means for doctoral programs was less than 0.50 and which had an approximately even distribution across the range are listed below, sometimes in paraphrased form. Several relevant quotations are included.

1. "Assist in analyses of data for theses": the means were all approximately "Some," with the range being 2.67 (Social Sciences) to 3.09 (Health).

Becoming a scholar is a collaborative apprenticeship; we supervisors share with students the process of doing research, writing it up, presenting it, submitting it, applying for grants. The writing, particularly, is always a collaborative enterprise-which means frequent feedbackand even help with revision/editing may be required. (Education)

2. "Assist doctoral students in development of teaching skills": the means were in the "Some" to "Substantial" range, varying from 3.39 (Engineering) to 3.82 (Humanities).

3. "Assign supervisors who are expert in the students' specific research fields": the means were all above 4.00 ("Considerable"), ranging from 4.11 (Social Sciences) to 4.45 (Biology). 
The fact that certain professors who engage in no research activity are authorized to direct master's and doctoral students seems to me to be nonsense. This situation, along with the lack of relationship between the thesis subjects and the areas of interest of the directors, explains a large part of the problems related to abandonment or the excessive length of studies at the doctoral level. (Business/Commerce)

4. "Provide a graduate student handbook. . . ." had a range from 4.00 (Engineering) to 4.28 (Humanities).

5. "Provide balance between direction and independence": the doctoral means for each discipline were generally somewhat above "Considerable," varying from 4.16 (Engineering) to 4.46 (Biology).

It's most important to provide a balance between supervisor's direction and student's independence. It is not up to the supervisor to provide the incentive for the student to finish a project, but it is up to the supervisor to set reasonable deadlines and return work promptly with appropriate recommendations. (Humanities)

An issue that supervisors are continually faced with is the balance between giving direction and guidance versus allowing the free progress of students. While it is desirable that students are as independent as possible, the demands of granting councils require high productivity. (Medicine)

Student-advisor relationships are very subtle. Know when to push, when to back off. Help without too much dependence. Supervision is about individuals and their growth. (Education)

6. "Ensure that students continually make progress": the doctoral means were about or somewhat above "Considerable," ranging from 3.97 (Social Sciences) to 4.38 (Biology).

7. "Help students revise research design if unforeseen problems occur": the doctoral means were generally higher than "Considerable," ranging from 4.00 (Social Sciences) to 4.49 (Biology).

8. "Hold regular progress meetings": the doctoral means were in the "Considerable" to "Great" range, varying from 4.15 (Social Sciences) to 4.56 (Business).

Graduate training is an apprenticeship program. The one-on-one relationship between student and supervisor is the strength of graduate education. A committee structure should function as a back-up to prevent breakdown of relations on either side. (Agriculture/Biology)

9. "Provide prompt feedback on draft chapters" had the highest doctoral mean (4.47), almost halfway between "Considerable" and "Great." The range was 4.32 (Physical Sciences) to 4.75 (Business). 
Table 3

Means of Responses of Supervisors, Classified by Major Discipline Areas, to Selected Questions About the Importance of University-Level Aspects of Supervision in Assisting Thesis Students to Complete Theses and Pass Final Oral Examinations in an Appropriate Period of Time

\begin{tabular}{|c|c|c|c|c|c|c|c|c|c|c|c|}
\hline \multirow[b]{3}{*}{ Aspect of supervision } & & \multicolumn{8}{|c|}{ Means of Responses } & \multirow{3}{*}{$\mathrm{n}$} & \multirow[b]{2}{*}{ Mean } \\
\hline & & Biol & Eng & Bus & PhySci & Health & $\mathrm{Ed}$ & SociSci & Hum & & \\
\hline & $\begin{array}{l}\text { Range of } \\
\text { number of } \\
\text { responses }\end{array}$ & $\begin{array}{l}120- \\
126\end{array}$ & $61-66$ & $16-21$ & $78-82$ & $74-82$ & $75-90$ & $\begin{array}{c}102- \\
118\end{array}$ & $\begin{array}{l}109- \\
114\end{array}$ & & Total \\
\hline \multirow{2}{*}{$\begin{array}{l}\text { 1. Appoint an appropriate administrator to } \\
\text { monitor the supervision provided to all } \\
\text { graduate students }\end{array}$} & Master's & 2.87 & 2.23 & 3.33 & 2.61 & 2.71 & 2.89 & 2.65 & 2.77 & 688 & 2.73 \\
\hline & Doctoral & 2.84 & 2.25 & 3.19 & 2.56 & 2.81 & 2.84 & 2.64 & 2.78 & 635 & 2.71 \\
\hline \multirow{2}{*}{$\begin{array}{l}\text { 2. Require that annual reports of students' } \\
\text { progress be submitted to the graduate } \\
\text { studies office/faculty }\end{array}$} & Master's & 3.19 & 2.61 & 3.24 & 2.74 & 2.94 & 3.03 & 3.24 & 2.92 & 699 & 3.00 \\
\hline & Doctoral & 3.23 & 2.79 & 3.25 & 2.94 & 2.97 & 3.16 & 3.32 & 3.13 & 651 & 3.11 \\
\hline
\end{tabular}

Note: The response categories were $1=$ None; $2=$ A little; $3=$ Some; $4=$ Considerable; and 5=Great; ( $9=$ Not applicable or No opinion). 
Table 4

Means of Responses of Supervisors, Classified by Major Discipline Areas, to Selected Questions About the Importance of Unit-Level Aspects of Supervision in Assisting Thesis Students to Complete Theses and Pass Final Oral Examinations in an Appropriate Period of Time

\begin{tabular}{|c|c|c|c|c|c|c|c|c|c|c|c|}
\hline \multirow{3}{*}{ Aspect of supervision } & & \multicolumn{8}{|c|}{ Means of Responses } & \multirow{3}{*}{$\mathrm{n}$} & \multirow[b]{2}{*}{ Mean } \\
\hline & & Biol & Eng & Bus & PhySci & Health & Ed & SocSci & Hum & & \\
\hline & $\begin{array}{l}\text { Range of } \\
\text { number of } \\
\text { responses }\end{array}$ & $\begin{array}{l}113- \\
129\end{array}$ & $62-68$ & $15-21$ & $75-83$ & $70-82$ & $73-91$ & $\begin{array}{l}100- \\
121\end{array}$ & $\begin{array}{l}102- \\
117\end{array}$ & & Total \\
\hline \multirow{2}{*}{$\begin{array}{l}\text { 1. Assign supervisors at the beginning } \\
\text { of students' programs }\end{array}$} & Master's & 4.40 & 4.18 & 3.14 & 3.86 & 3.87 & 3.73 & 3.65 & 3.49 & 691 & 3.85 \\
\hline & Doctoral & 4.44 & 4.22 & 3.19 & 3.92 & 4.18 & 4.03 & 3.75 & 3.68 & 640 & 4.00 \\
\hline \multirow{2}{*}{$\begin{array}{l}\text { 2. Assign supervisors who are expert in the } \\
\text { students' specific research fields }\end{array}$} & Master's & 4.38 & 4.33 & 4.00 & 4.22 & 4.03 & 3.76 & 3.78 & 4.00 & 688 & 4.06 \\
\hline & Doctoral & 4.45 & 4.40 & 4.40 & 4.36 & 4.33 & 4.15 & 4.11 & 4.29 & 638 & 4.30 \\
\hline \multirow{2}{*}{$\begin{array}{l}\text { 3. Match personalities of supervisors and } \\
\text { students }\end{array}$} & Master's & 2.64 & 2.73 & 3.16 & 2.89 & 2.94 & 2.96 & 2.97 & 3.15 & 666 & 2.91 \\
\hline & Doctoral & 2.68 & 2.83 & 3.33 & 2.87 & 3.06 & 3.12 & 2.90 & 3.16 & 613 & 2.95 \\
\hline \multirow{2}{*}{$\begin{array}{l}\text { 4. Provide a graduate student handbook } \\
\text { which includes program procedures, } \\
\text { responsibilities of graduate students and } \\
\text { supervisors, funding available, and } \\
\text { publication policies }\end{array}$} & Master's & 4.16 & 4.06 & 4.14 & 4.00 & 4.11 & 4.25 & 4.14 & 4.24 & 707 & 4.15 \\
\hline & Doctoral & 4.13 & 4.00 & 4.13 & 4.07 & 4.05 & 4.16 & 4.20 & 4.28 & 655 & 4.14 \\
\hline \multirow{2}{*}{$\begin{array}{l}\text { 5. Involve one or two other faculty } \\
\text { members in the student's research } \\
\text { throughout the thesis project }\end{array}$} & Master's & 3.88 & 2.59 & 3.35 & 2.95 & 3.43 & 3.37 & 3.41 & 3.02 & 693 & 3.30 \\
\hline & Doctoral & 3.96 & 3.19 & 3.56 & 3.38 & 3.85 & 3.86 & 3.72 & 3.38 & 650 & 3.64 \\
\hline \multirow{2}{*}{$\begin{array}{l}\text { 6. Provide settings in which students can } \\
\text { present progress reports to faculty members } \\
\text { and other graduate students for feedback }\end{array}$} & Master's & 4.42 & 3.71 & 3.85 & 3.79 & 4.22 & 3.74 & 3.70 & 3.62 & 708 & 3.90 \\
\hline & Doctoral & 4.48 & 3.91 & 4.31 & 4.21 & 4.44 & 4.10 & 3.98 & 3.90 & 661 & 4.16 \\
\hline
\end{tabular}

Note: $\quad$ The response categories were $1=$ None; $2=\mathrm{A}$ little; $3=$ Some; $4=$ Considerable; and $5=$ Great; ( $9=$ Not applicable or No opinion). 
Table 5

Means of Responses of Supervisors, Classified by Major Discipline Areas, to Selected Questions About the Importance of Supervisor-Level Aspects of Supervision in Assisting Thesis Students to Complete Theses and Pass Final Oral Examinations in an Appropriate Period of Time.

\begin{tabular}{|c|c|c|c|c|c|c|c|c|c|c|c|}
\hline \multirow{3}{*}{ Aspect of supervision } & & \multicolumn{8}{|c|}{ Means of Responses } & \multirow{3}{*}{ n } & \multirow{3}{*}{$\frac{\text { Mean }}{\text { Total }}$} \\
\hline & & Biol & Eng & Bus & PhySci & Health & Ed & SocSai & Hum & & \\
\hline & $\begin{array}{l}\text { Range of } \\
\text { number of } \\
\text { responses }\end{array}$ & $\begin{array}{l}110- \\
129\end{array}$ & $53-68$ & $15-21$ & $74-83$ & $70-83$ & $71-91$ & $\begin{array}{l}98- \\
122\end{array}$ & $\begin{array}{l}101- \\
118\end{array}$ & & \\
\hline \multirow{2}{*}{$\begin{array}{l}\text { 1. Provide a balance between supervisor's } \\
\text { direction and student's independence }\end{array}$} & Master's & 4.21 & 3.79 & 4.24 & 3.91 & 4.10 & 4.26 & 4.08 & 4.24 & 695 & 4.11 \\
\hline & Doctoral & 4.46 & 4.16 & 4.25 & 4.18 & 4.42 & $4 . \overline{43}$ & 4.28 & 4.42 & 647 & 4.35 \\
\hline \multirow{2}{*}{$\begin{array}{l}\text { 2. Ensure that students continually } \\
\text { make progress }\end{array}$} & Master's & 4.48 & 4.27 & 4.43 & 4.14 & 4.24 & 4.13 & 4.05 & 4.10 & 697 & 4.21 \\
\hline & Doctoral & 4.38 & 4.22 & 4.19 & 4.10 & 4.20 & 4.04 & 3.97 & 4.15 & 646 & 4.16 \\
\hline \multirow[t]{2}{*}{ 3. Motivate the students continually } & Master's & 4.01 & 3.91 & 3.85 & 3.45 & 3.66 & 3.41 & 3.38 & 3.49 & 705 & 3.62 \\
\hline & Doctoral & 3.86 & 3.65 & 3.73 & 3.33 & 3.52 & 3.13 & 3.13 & 3.41 & 654 & 3.45 \\
\hline \multirow[t]{2}{*}{ 4. Provide personal counselling } & Master's & 3.30 & 3.41 & 3.48 & 3.07 & 3.31 & 2.98 & 2.86 & 3.27 & 694 & 3.17 \\
\hline & Doctoral & 3.26 & 3.35 & 3.50 & 3.10 & 3.20 & 2.99 & 2.69 & 3.23 & 640 & 3.12 \\
\hline \multirow{2}{*}{$\begin{array}{l}\text { 5. Encourage students to use methodologies } \\
\text { with which students are comfortable }\end{array}$} & Master's & 3.07 & 3.23 & 3.65 & 2.87 & 3.18 & 3.75 & 3.13 & 3.78 & 642 & 3.31 \\
\hline & Doctoral & 2.96 & 3.11 & 3.40 & 2.92 & 3.00 & 3.68 & 3.07 & 3.78 & 595 & 3.23 \\
\hline \multirow{2}{*}{$\begin{array}{l}\text { 6. Ensure that the thesis project does } \\
\text { not grow excessively }\end{array}$} & Master's & 4.32 & 4.37 & 4.67 & 4.05 & 4.34 & 4.50 & 4.44 & 4.59 & 708 & 4.39 \\
\hline & Doctoral & 4.13 & 4.15 & 4.44 & 4.04 & 4.17 & 4.30 & 4.28 & 4.60 & 661 & 4.26 \\
\hline \multirow{2}{*}{$\begin{array}{l}\text { 7. Help students revise research design if } \\
\text { unforeseen problems require such revision }\end{array}$} & Master's & 4.57 & 4.30 & 4.33 & 4.32 & 4.38 & 4.41 & 4.16 & 4.41 & 707 & 4.37 \\
\hline & Doctoral & 4.49 & 4.17 & 4.19 & 4.16 & 4.27 & 4.36 & 4.00 & 4.42 & 659 & 4.28 \\
\hline
\end{tabular}


Table 5 (continued)

\begin{tabular}{|c|c|c|c|c|c|c|c|c|c|c|c|}
\hline \multirow[b]{3}{*}{ Aspect of supervision } & & \multicolumn{8}{|c|}{ Means of Responses } & \multirow{3}{*}{$\mathrm{n}$} & \multirow{3}{*}{$\frac{\text { Mean }}{\text { Total }}$} \\
\hline & & Biol & Eng & Bus & PhySci & Health & Ed & SocSci & Hum & & \\
\hline & $\begin{array}{l}\text { Range of } \\
\text { number of } \\
\text { responses }\end{array}$ & $\begin{array}{l}110- \\
129\end{array}$ & $53-68$ & $15-21$ & $74-83$ & $70-83$ & $71-91$ & $\begin{array}{l}98- \\
122\end{array}$ & $\begin{array}{l}101- \\
118\end{array}$ & & \\
\hline \multirow{2}{*}{$\begin{array}{l}\text { 8. Hold regular progress report } \\
\text { meetings with students }\end{array}$} & Master's & 4.56 & 4.48 & 4.48 & 4.22 & 4.43 & 4.38 & 4.26 & 4.29 & 712 & 4.37 \\
\hline & Doctoral & 4.49 & 4.42 & 4.56 & 4.28 & 4.39 & 4.33 & 4.15 & 4.31 & 663 & 4.34 \\
\hline \multirow{2}{*}{$\begin{array}{l}\text { 9. Set deadlines for submission of } \\
\text { particular parts of thesis }\end{array}$} & Master's & 3.78 & 3.85 & 4.10 & 3.38 & 3.83 & 3.65 & 3.92 & 3.91 & 704 & 3.78 \\
\hline & Doctoral & 3.67 & 3.79 & 4.06 & 3.24 & 3.73 & 3.47 & 3.77 & 3.76 & 656 & 3.65 \\
\hline \multirow{2}{*}{$\begin{array}{l}\text { 10. Provide prompt feedback on draft } \\
\text { chapters of thesis }\end{array}$} & Master's & 4.51 & 4.40 & 4.71 & 4.31 & 4.40 & 4.54 & 4.46 & 4.56 & 711 & 4.47 \\
\hline & Doctoral & 4.55 & 4.34 & 4.75 & 4.32 & 4.39 & 4.56 & 4.42 & 4.59 & 664 & 4.47 \\
\hline \multirow{2}{*}{$\begin{array}{l}\text { 11. Provide assistance in orienting students } \\
\text { towards appropriate behavior in } \\
\text { oral examinations }\end{array}$} & Master's & 4.03 & 3.78 & 3.90 & 3.56 & 3.96 & 4.02 & 3.68 & 4.01 & 663 & 3.88 \\
\hline & Doctoral & 4.03 & 3.69 & 3.88 & 3.62 & 3.92 & 4.12 & 3.53 & 3.99 & 660 & 3.85 \\
\hline
\end{tabular}

Note: The response categories were 1=None; $2=\mathrm{A}$ little; $3=$ Some; 4=Considerable; and 5=Great; (9=Not applicable or No opinion). 
Differences. In the following section other supervisory aspects whose means for a disciplinary area for doctoral programs were either 0.30 above or 0.30 below the overall mean for the aspect are identified. (See Table 6.) That is, the entry of either $\mathrm{H}$ (higher) or L (lower) in Table 6 indicates that the discipline mean varied substantially from the mean for the aspect and not that the mean itself was high or low. The profiles for the eight discipline areas were dissimilar. Some information about means for Biology at the master's level is also included.

Biology had substantially higher doctoral means on five aspects: assisting in preparing journal manuscripts, assigning supervisors at the beginning of the program, involving other faculty members in students' research, providing settings for progress reports, and motivating continually.

Our students are associated with particular supervisors as part of the acceptance process. Switching is rare. (Agriculture/Biology)

Health also had only substantially higher doctoral means, but for three aspects which generally indicate a stronger focus on dveloping scholarship: assisting with development of skills in preparing research grant applications, conference paper proposals, and journal manuscripts.

Three substantially lower doctoral means were obtained for Engineering: assisting with refining and improving theses, assisting with development of skills in preparing research grant applications, and involving other faculty members in students' research.

The biggest problem lies with ill-defined research topics. (Engineering)

Social Sciences also had only lower doctoral means with the five being related to conference paper proposals, journal manuscripts, motivating continually, personal counselling, and orienting to the final oral examination.

The four other disciplinary areas had mixtures of higher and lower doctoral means. Humanities had substantially lower means for assisting with journal manuscripts and assigning supervisors early but substantially higher means for both encouraging use of methodologies with which students are comfortable and ensuring that the thesis project does not grow excessively. Education also had higher emphasis on comfort with methodologies, together with lower emphasis on assisting in data collection and motivating continually. More variability was shown by Business which had four substantially higher meansrefining and improving theses, matching personalities, providing personal counselling, and setting deadlines-and two substantially lower means-assisting in developing thesis proposals, and assigning supervisors early. Physical Sciences also showed considerable variability with substantially higher means 
for assisting in data collection and with journal manuscripts and substantially lower means for assisting in developing skills for research grant applications, emphasis on comfort with methodologies, and setting deadlines.

Commonalities. Some commonalties are also of interest. Biology, Physical Sciences, and Health all had substantially higher means on assisting with preparing journal manuscripts which seems to reflect their well-known emphasis on encouraging publication by graduate students. Also, several respondents from different disciplines provided these comments about assignment of supervisors:

Should consider historic success rate of supervisors when assigning students to them. (Engineering)

PhD supervision should be outlined in detail in a policy paper that has the status of a contract between the university, department, and

Table 6

Aspects of Supervision in Which the Means of Supervisors' Responses in a Doctoral Discipline Area Were Either Substantially Higher or Substantially Lower Than the Overall Response Means

\begin{tabular}{|c|c|c|c|c|c|c|c|c|c|}
\hline ASPECT OF SUPERVISION & BIOL & ENG & Bus & PhysSCI & Health & ED & SocScI & HuM & MEAN \\
\hline 1. Thesis proposal development & & & $\mathrm{L}$ & & & & & & 4.00 \\
\hline 2. Collection of data & & & & $\mathrm{H}$ & & $\mathrm{L}$ & & & 2.41 \\
\hline 4. Refine and improve theses & & $\mathrm{L}$ & $\mathrm{H}$ & & & & & & 3.82 \\
\hline 6. Research grant applications & & $\mathrm{L}$ & & $\mathrm{L}$ & $\mathrm{H}$ & & & & 3.48 \\
\hline 7. Conference paper proposals & & & & & $\mathrm{H}$ & & $\mathrm{L}$ & & 3.69 \\
\hline 8. Journal manuscripts & $\mathrm{H}$ & & & $\mathrm{H}$ & $\mathrm{H}$ & & $\mathrm{L}$ & $\mathbf{L}$ & 3.83 \\
\hline 1. Assign supervisors early & $\mathrm{H}$ & & $\mathbf{L}$ & & & & & $\mathbf{L}$ & 4.00 \\
\hline 3. Match personalities & & & $\mathrm{H}$ & & & & & & 2.95 \\
\hline 5. Involve other faculty & $\mathrm{H}$ & $\mathrm{L}$ & & & & & & & 3.64 \\
\hline 6. Present progress reports & $\mathrm{H}$ & & & & $\mathrm{H}$ & & & & 4.16 \\
\hline 3. Motivate continually & $\mathrm{H}$ & & & & & $\mathrm{L}$ & $\mathbf{L}$ & & 3.45 \\
\hline 4. Provide personal counselling & & & $\mathrm{H}$ & & & & $\mathbf{L}$ & & 3.12 \\
\hline 5. Comfortable methodologies & & & & $\mathrm{L}$ & & $\mathrm{H}$ & & $\mathrm{H}$ & 3.23 \\
\hline 6. Not grow excessively & & & & & & & & $\mathrm{H}$ & 4.26 \\
\hline 9. Set deadlines & & & $\mathrm{H}$ & $\mathrm{L}$ & & & & & 3.65 \\
\hline 10. Orient to oral examination & & & & & & & $\mathrm{L}$ & & 3.85 \\
\hline
\end{tabular}

Note: "Substantially" meant a difference of at least 0.30 from the overall mean: $\mathrm{H}=$ higher; $\mathrm{L}=$ lower. 
supervisor on the one-hand and the student on the other. Supervisors should be negotiated, not assigned. (Humanities)

Entirely too little attention is paid to student personality as a crucial variable in success or failure in graduate programs. (Mathematics/Statistics)

Essential to assign supervisors at start of program. (Physical Sciences)

One of the big problems today in Canadian universities is promotion of the myth of equality. Not all faculty are equally prepared to assist students with an MA or PhD level thesis or dissertation. Some people teach at the graduate level because they have been around longer and their feelings would be hurt if they did not. (Social Work)

Also, both Education and Social Sciences had substantially lower means for motivating continually which may seem to be inconsistent with the general perception of attitudes in these disciplinary areas. The variation in discipline means at the master's level was often similar to that observed at the doctoral level. However, the master's level means for Biology were higher than the overall mean and the means for most of the other disciplines by at least 0.3 for these supervisory aspects: assign supervisors who are expert in the student's specific research fields; involve other faculty members; provide settings for progress reports; and motivate continually.

\section{Other Matters}

Several other matters were addressed by respondents in their comments. These especially related to (a) funding of students, (b) completion, and (c) recognition of the value of supervision. The first set of quotations involve the funding of graduate students which was not included in the supervisors' questionnaire because it was a major component of the graduate coordinators' questionnaire.

Students need to be made aware of the total amount of funding that will be available during their study: guarantee of funds minimizes many difficulties which will be encountered. (Physical Sciences)

One of the greatest influences upon success is funding. (English)

The question of financing graduate studies, which is not treated in this questionnaire, is, in my opinion, the major problem for which remedies must be found in order for Canada to get out of its growing under-development. (Agriculture/Biology)

The major impediment to normal progress on thesis or dissertation has been inadequate financial support which has required students to seek employment in order to meet basic expenses. (Social Sciences) 
Respondents also provided comments relevant to time to complete graduate programs. The following are typical:

There is some danger that we are now over-emphasizing the timeto-completion aspect. We also need reflection time, proper time for research, and a thoughtful approach. (Social Sciences)

Theses that take years to complete are usually the last pieces of substantial research that these students undertake, instead of being, as they should be, the first. The statistics on my own students convince me that the faster they have completed their doctoral programs, the more productive and original scholars they are likely to be. Parkinson's Law is otherwise in full operation. (Humanities)

I am strongly of the opinion that, in the humanities at least, the doctoral program-courses, comprehensives, and thesis-should be treated as a single overall process, rather than sequential, as often happens now. Thesis topic should be isolated and developed with the supervisor at the beginning of the program, and work in courses and preparation for comprehensives should be regarded as a whole, with frequent crossovers. If this is done, many more students than at the present could complete the PhD within reach of the statutory minimum of two years after the M.A. steadily and without undue strain. (Humanities)

Other quotations were added relevant to recognition of the value of supervision of graduate students:

Grad supervision is a very undervalued contribution in university circles, both with regard to work and rewards. (Agriculture/Biology)

A great deal of supervision would be better administered if the very activity of supervision of master's and doctoral students were better recognized and valued by the universities. (Library Science)

Professors who supervise theses should be given credit as it is a long, difficult process for the student and the supervisor. (Education)

The excellence of graduate students in the biomedical sciences is exclusively a consequence of the supervisor, not to any great extent the student (assuming a reasonably good level of overall student competence i.e., intelligence, work habits, mental discipline). (Medicine)

\section{Generalizations}

Considerable support was evident for restricting graduate supervision to faculty members active in research and publication, for assigning supervisors who are expert in the students' specific research fields, for having students conduct 
research closely related to their supervisor's research, and for assigning supervisors at the beginning of students' programs. Involvement of students in the selection of supervisors was favored by several respondents in their written comments. While recognizing that many variables affect the number of thesisroute graduate students that one faculty member can supervise effectively, those who favored a restriction on the maximum number tended to select five as the maximum.

In general, respondents considered that "Substantial" assistance should be provided to graduate students in development of thesis proposals and in refinement and improvement of theses. Less support was obtained for collection and analysis of data but responses for these two functions varied substantially across discipline areas. More assistance was advocated for master's students than for doctoral students.

Between "Some" and "Substantial" support was evident for assistance to doctoral students in (a) development of teaching skills and research grant applications and (b) preparation of conference paper proposals and journal manuscripts.

The 10 practices which were perceived to be the most important in assisting students to successfully complete their theses in an appropriate time and pass the final oral examination were as follows: provide prompt feedback; provide balance between supervisor's direction and student's independence; hold regular progress report meetings; assign supervisors who are expert in the students' specific research fields; help students revise research design if unforeseen problems require such revision; ensure that the thesis project does not grow excessively; ensure that students continually make progress; provide settings for students to present progress reports for feedback; provide a detailed student handbook; and assign supervisors at the beginning of student' programs.

Several of these practices have commonly been identified as important in the literature (e.g., the holding of regular meetings-Moses, 1992; Powles, 1993), whereas others were identified in interviews conducted earlier in this study (e.g. help students revise research design if unforeseen problems require such revision).

When the supervisors' responses were categorized by discipline area for doctoral programs, several aspects of supervision were viewed as important across all disciplines, e.g., ensure that students continually make progress, provide prompt feedback on draft chapters, and hold regular progress report meetings with students. Other aspects showed substantial differences across disciplines, for example, assisting with preparation of manuscripts for submission to refereed journals was strongly supported by supervisors in Biology, Physical Sciences, and Health but far less strongly by supervisors in Social 
Sciences and Humanities. Different levels of support for aspects of supervision were noted for each discipline, for example, Biology and Health each were substantially higher in their level of support for five and three supervisory aspects respectively, while Social Sciences was substantially lower for five supervisory aspects. The Biology responses showed the greatest overall level of support for many of the supervisory aspects listed on the questionnaire at both the master's and doctoral levels.

\section{Concluding Comment}

Many publications (e.g., Moses, 1992; Smith 1991) have emphasized the importance of effective practices in the supervision of graduate students. "Importance" and "effectiveness" relate to many aspects of the graduate experience, including the development of skills, knowledge, and attitudes (e.g., Blume, 1987); the research output (e.g., Gumport, 1993); satisfaction and status of supervisors (e.g., Moses, 1992; Powles, 1993); and benefits to students, supervisors, departments, and universities (e.g., Bowen \& Rudenstine, 1992).

The research literature on graduate supervision, however, is not extensive. Hopefully, this project has helped to overcome this defect by providing information from a large number of expert supervisors in many disciplines and universities across Canada about aspects of the supervision process. Its findings generally support the propositions identified in the literature overview but they point out that emphases on most supervisory practices differ across disciplines. Also, positions held by individual supervisors within a discipline tend to be highly variable, so the nature of graduate supervision is quite idiosyncratic.

Some of the matters discussed in this paper had not been raised in detail in the graduate studies literature. For example, little attention has been paid to the assistance given by supervisors to the activities of students shown in Figure 1 which are usually not directly related to preparation of the thesis, for example, development of skills in preparation of research grant applications, conference paper proposals, and journal manuscripts. Other supervisory aspects which were explored in this study and which are either ignored in the literature or dealt with only briefly are provision of personal counselling, encouraging students to use methodologies with which they are comfortable, and helping students to revise the research design if unforeseen problems require such revisions. Further research on such aspects should be conducted.

Comments provided by individual supervisors also yielded important insights which were not the subject of specific questions, as shown by this quotation: 
Other important tasks of supervisors: advise students when to stop research and prepare final document; advise how much reading/experimentation/analysis will normally be expected. (English)

The framework in Figure 1 emphasizes inputs and outputs relevant to both the supervisory process and the activities of graduate students. With respect to inputs, the results of this study reinforced the influence of the culture of the discipline, characteristics of the supervisor, and elements of the infrastructure upon the supervisory process. The aspects of supervision shown in Figure 1 were also identified as important in this study, together with the supervisor's involvement with activities of the student, although both of these varied by discipline. Outputs were not specifically addressed as such in this study although they are directly related to student activities.

Administrators and graduate supervisors should pay attention to the list of the most important practices identified by respondents in this study while simultaneously recognizing that some differences exist between disciplines, between supervisors, and between master's and doctoral programs. The approaches taken are contingent on many factors, as Burgess et al. (1994) described. Despite these differences, some Canadian universities may consider following the proposed procedure at The University of Melbourne that all new staff members who want to supervise graduate students will be required to attend orientation seminars on effective supervisory practices. These seminars should address the issues raised in this and other studies. Such an approach should at least ensure that new supervisors are aware of the relevant issues and that they reflect upon the type of supervisory style that they will use. Consequently, over time, effectiveness of graduate supervision could be improved, the overall quality of the graduate experience could be enhanced, and some of the barriers to graduate program completion could be overcome.

\section{References}

Association of Universities and Colleges of Canada. (1992). Report of the AUCC Task Force on the Report of the Commission of Inquiry on Canadian University Education. Ottawa, ON: Author.

Ballard, B., \& Clanchy, J. (1993). Supervising students from overseas. In D. J. Cullen (Ed.), Quality in PhD education (pp. 61-73). Canberra: Australian National University.

Blume, S. (1987). A European perspective. Economic and Social Research Newsletter (U.K.) 60 , June, 14-15.

Bowen, W. G., \& Rudenstine, N. L. (1992). In pursuit of the PhD. Princeton, NJ:

Princeton University Press. 
Burgess, R. G., Pole, C. J., \& Hockey, J. (1994). Strategies for managing and supervising the social sciences $\mathrm{PhD}$. In R. G. Burgess (Ed.), Postgraduate education and training in the social sciences: Processes and products (pp. 13-33). London: Jessica Kingsley.

Canadian Association for Graduate Studies. (1992). Statistical Report. Ottawa, ON: Author. Christopherson, D., Boyd, R. L. F., Fleming, I., Macdonald, I. G., Mylroi, M. G., Wardlaw, A. C., \& Willmott, J. C. (1992). Research student and supervisors: An approach to good supervisory practice. Swindon, UK: Science and Engineering Research Council.

Conrad, C. F., Haworth, J. G., \& Millar, S. B. (1993). A silent success: Master's education in the United States. Baltimore, MD: The John Hopkins University Press.

Council of Graduate Schools. (1990). Research student and supervisor. Washington, DC: Author.

Donald, J. G., Saroyan, A., \& Denison, D. B. (1994, June). Graduate student supervision policies and procedures: A case study of issues and factors affecting graduate study. Paper presented at the annual meeting of the Canadian Society for the Study of Higher Education, Calgary, AB.

Gumport, P. J. (1993). Graduate education and organized research in the United States. In B. R. Clark (Ed.), The research foundations of graduate education: Germany, Britain, France, United States, Japan (pp. 225-260). Berkeley, CA: University of California Press.

Hill, T., Acker, S., \& Black, E. (1994). Research students and their supervisors in education and psychology. In R. G. Burgess (Ed.), Postgraduate education and training in the social sciences: Processes and products (pp. 53-72). London: Jessica Kingsley.

Holdaway, E. A., Deblois, C., \& Winchester, I. S. (1994). Practices and opinions reported by coordinators of graduate programs. Interchange, 25(1), 65-86.

Moses, I. (1985). Supervising postgraduates. Sydney, Australia: Higher Education Research and Development Society of Australasia, c/o University of New South Wales.

Moses, I. (1992). Good supervisory practice. In I. Moses (Ed.), Research training and supervision (pp. 11-15). Proceedings of a conference sponsored by the Australian Vice-Chancellors' Committee and the Australian National Board of Employment, Education and Training. Canberra: Australian Research Council.

Phillips, E. M., \& Pugh, D. S. (1987). How to get a PhD. Milton Keynes, UK: Open University Press.

Powles, M. (1989). How's your thesis going? Melbourne, Australia: Centre for the Study of Higher Education, University of Melbourne.

Powles, M. (1993). Staff development for PhD supervision. In D. J. Cullen (Ed.), Quality in PhD education (pp. 75-84). Canberra: Australian National University.

Royal Society of Canada. (1991). Realizing the potential: A strategy for university research in Canada. Ottawa, ON: Author.

Salmon, P. (1992). Achieving a PhD—ten students' experience. Oakhill, Stoke-on-Trent, England: Trentham Books.

Smith, S. L. (1991). Report: Commission of Inquiry on Canadian University Education. Ottawa, ON: Association of Universities and Colleges of Canada. 